\title{
Cutaneous manifestations of internal malignancies in a tertiary health care hospital of a developing country
}

\author{
Manifestações cutâneas de doenças malignas em um hospital terciário de um \\ país em desenvolvimento
}

\author{
Alex G. Ortega-Loayza ${ }^{1}$ \\ Ericson L. Gutierrez ${ }^{3}$ \\ Lucia Bobbio $^{5}$
}

\author{
Willy Ramos ${ }^{2}$ \\ Patricia Chavez de Paz ${ }^{4}$ \\ Carlos Galarza ${ }^{6}$
}

\begin{abstract}
In a public hospital in Lima, Peru, 24 patients with 16 types of paraneoplastic dermatoses were identified by data collection. The most frequent dermatosis was dermatomyositis (four patients). The other dermatoses were malignant acanthosis nigricans, palmoplantar keratoderma, bullous dermatoses, lymphomatoid papulosis, edematous scarring vasculitic panniculitis, Norwegian scabies, primary systemic amyloidosis, necrolytic migratory erythema, infective dermatitis, pancreatic panniculitis, generalized pruritus, Lesser-Trelat syndrome, and acquired ichthyosis. Most of these paraneoplastic dermatoses were diagnosed before (45.8\%) or at the time of (38.5\%) the diagnosis of the underlying malignancy. The most frequent underlying malignancies were lymphoma, adenocarcinomas of the upper digestive tract, and malignant neoplasms of the pancreas. The average age of the patients was $47.0 \pm 16.9$ years and the length of the disease since diagnosis was 13.7 months. The mortality rate was $75 \%$. Paraneoplastic dermatoses are rare dermatologic entities that are difficult to diagnose. Surveillance is also hampered when patients do not have easy access to health care centers due to financial and geographical issues. However, when identified, they might facilitate the early diagnosis of an associated tumor and contribute to increase the surveillance of patients.
\end{abstract}

Keywords: Dermatomyositis; Lymphoma; Paraneoplastic syndromes

Resumo: Em um hospital público em Lima, Peru, 24 pacientes com 16 tipos de dermatoses paraneoplásicas foram identificados por meio de coleta de dados. A dermatose mais frequente foi dermatomiosite (quatro pacientes). As outras dermatoses foram acantose maligna, queratodermia palmoplantar, dermatoses bolhosas, papulose linfomatóide, cicatriz edematosa, paniculite e vasculite, escabiose norueguesa, amiloidose sistêmica primária, eritema necrolítico migratório, dermatite infecciosa, paniculite pancreática, prurido generalizado, sinal de Leser-Trelat e ictiose adquirida. Grande parte dessas dermatoses foi diagnosticada antes $(45,8 \%)$ ou no momento $(38,5 \%)$ do diagnóstico do tumor subjacente. Os tumores malignos mais frequentes foram linfoma, adenocarcinomas do trato digestivo superior e neoplasias malignas do pâncreas. A idade média dos pacientes foi de $47.0 \pm 16.9$ anos e a duração da doença desde o diagnóstico foi de 13,7 meses. A taxa de mortalidade foi de $75 \%$. Dermatoses paraneoplásicas são condições dermatológicas raras de difícil diagnóstico. O controle também é prejudicado quando pacientes não têm acesso fácil à centros de saúde por questões financeiras ou geográficas. No entanto, quando identificadas, elas podem facilitar o diagnóstico precoce de um tumor associado e contribuir para um aumento do controle dos pacientes.

Palavras-chave: Dermatomiosite; Linfoma; Síndromes paraneoplásicas

\footnotetext{
Approved by the Advisory Board and accepted for publication on 27.11.09.

* Work conducted at the Virginia Commonwealth University, Richmond - Virginia, USA

Conflict of interest: None / Conflito de interesse: Nenhum

Financial funding: None / Suporte financeiro: Nenhum

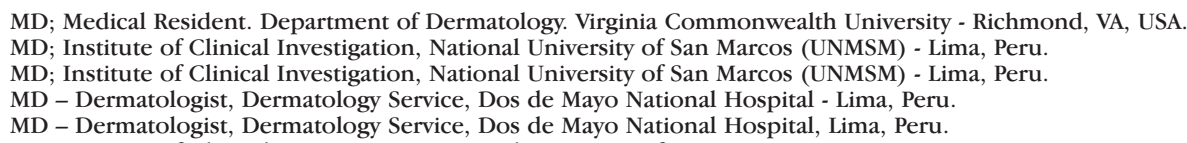




\section{INTRODUCTION}

Paraneoplastic dermatoses are ailments that arise in association with a malignancy elsewhere in the body. These dermatoses represent a heterogeneous group of clinical manifestations which might appear in association with a malignancy. They are the second most common paraneoplastic disease after the endocrinologic paraneoplastic syndromes. 1,2 Paraneoplastic dermatoses are characterized by a diverse range of cutaneous changes, some of which appear benign. Therefore, they may go unnoticed by the physician. ${ }^{1}$

The criteria for a certain set of skin diseases to be considered paraneoplastic dermatoses are shown in table 1 . In fact, the first two criteria (major criteria) are sufficient to consider a dermatosis as paraneoplastic. ${ }^{1-4}$

The frequency with which some benign dermatoses are associated with underlying malignancy suggests that this is not random; however in most cases it is difficult to demonstrate a cause-effect relationship with the primary tumor. The current literature suggests that these phenomena are the result of the interaction between the tumor, some mediator factors and the involved tissue. ${ }^{3,4}$ The mediators are generally polypeptides, hormones, cytokines, antibodies and growth factors. These mediator factors interfere with cell to cell communication, resulting in an increase of cellular activity. ${ }^{3,4}$ In a previous review, more than 40 dermatoses were found to be reported as paraneoplastic. ${ }^{3}$ The paraneoplastic dermatoses might be categorized in three different groups (Table 2).

In this study, we reported 24 cases of paraneoplastic dermatoses as well as the underlying malignancies in a tertiary health care hospital of a developing country.

\section{CASE REPORTS}

In the Dos de Mayo National Hospital, Lima, Peru, between July 1993 and June 2007, we found 24
TABLE 1: Curth's criteria to diagnose paraneoplastic dermatoses

\begin{tabular}{ll}
\hline Type of Criteria & Diagnostic Criteria \\
\hline Major & $\begin{array}{l}\text { Both conditions begin almost at } \\
\text { the same time }\end{array}$ \\
Major & $\begin{array}{l}\text { Both conditions follow a parallel } \\
\text { course }\end{array}$ \\
Minor & $\begin{array}{l}\text { Neither the presentation nor the } \\
\text { course of the disease depends on } \\
\text { each other. }\end{array}$ \\
Minor & $\begin{array}{l}\text { A specific tumor produces a } \\
\text { characteristic cutaneous } \\
\text { manifestation }\end{array}$ \\
& $\begin{array}{l}\text { The dermatoses are not common } \\
\text { in the general population }\end{array}$ \\
Minor & $\begin{array}{l}\text { There is a high percentage of } \\
\text { association between both conditions }\end{array}$ \\
\hline
\end{tabular}

patients with 16 types of paraneoplastic dermatoses using data collection (Figure 1-6). The incidence of paraneoplastic dermatoses was approximately $4.5 \%$ every year. $66.7 \%$ were male and $33.3 \%$ female. The average age of the patients was $47.0 \pm 16.9$ years-old, $20(74.9 \%)$ patients were between 30 and 69 years old.

At the time, the average duration of illness at the diagnosis of malignancy was 13.7 months with a fatal outcome in 18 patients (75.0 \%). In $45.8 \%$ patients, the diagnosis of paraneoplastic dermatoses was made before the diagnosis of cancer; in $38.5 \%$ of patients the diagnosis was made simultaneously and in the rest the diagnosis of paraneoplastic dermatosis was made after the diagnosis of the neoplasia.

TABLE 2: Classification of paraneoplastic dermatoses

\begin{tabular}{lll}
\hline $\begin{array}{l}\text { Type of Paraneoplastic } \\
\text { Dermatoses }\end{array}$ & Characteristic & Paraneoplastic dermatosis \\
\hline Mandatory & $\begin{array}{l}\text { Always or very frequently } \\
\text { are paraneoplastic. }\end{array}$ & $\begin{array}{l}\text { Acanthosis nigricans, erythema gyratum repens, paraneoplastic } \\
\text { acrokeratosis, hypertrichosis lanuginosa acquisita, necrolytic } \\
\text { migratory erythema, paraneoplastic pemphigus. }\end{array}$ \\
Optional & $\begin{array}{l}\text { Appearance may or may } \\
\text { not be related to } \\
\text { malignancy }\end{array}$ & $\begin{array}{l}\text { Migratory thrombophlebitis, Sweet's syndrome, dermatomyositis, } \\
\text { pyoderma gangrenosum, erythema annular centrifugum, } \\
\text { Lesser-Trelat syndrome }\end{array}$ \\
Occasional & $\begin{array}{l}\text { Sign and symptoms rarely } \\
\text { appear related to malignancy }\end{array}$ & $\begin{array}{l}\text { Amyloidosis, cryoglobulinemia, hyperpigmentation, ichthyosis, } \\
\text { herpes zoster. }\end{array}$ \\
\hline
\end{tabular}



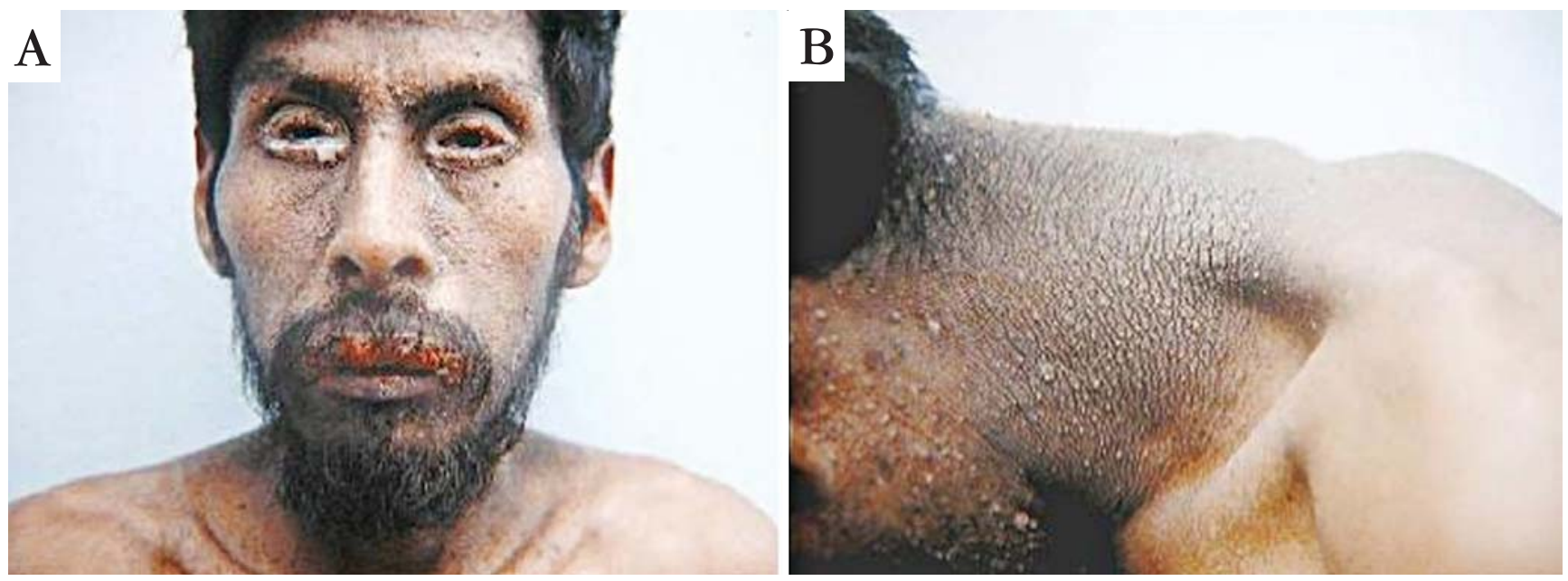

FigurE 1: A. 33 year old male with peri-orificial keratotic papules; B. Same patient showing velvety hyperpigmentation of the neck

When a dermatosis was diagnosed before the neoplasia, the diagnosis was made $7.5 \pm 4.2$ months before (range 3-18 months) (Table 3). On the other hand, when a dermatosis was diagnosed after the neoplasia the diagnosis was made $6.8 \pm 1.0$ months after (range 6-8 months) (Table 3).

Four patients, who had the diagnosis of infective dermatitis, Norwegian scabies acquired ichthyosis and tripe palms, showed reactive serology for HTLV-I (Human T-Lymphotropic virus) by ELISA (Enzyme Lynked immunosorbent Assay).

The most frequent dermatoses were dermatomyositis and immuno-bullous dermatoses. The most frequent underlying malignancies were lymphoma, upper digestive tract adenocarcinomas and malignant neoplasm of pancreas.

In eight patients, the average time between diagnosis and remission of the malignancy after treatment was between 15 days and 12 months after the time of diagnosis of the dermatoses. In the other ones, the dermatoses remain unchanged.

\section{DISCUSSION}

The clinical characteristics of paraneoplastic dermatoses in our country seem to be similar to those in developed countries; ${ }^{2-4,9,10}$ however, our patient population delayed seeking medical attention resulting in a high mortality rate. Also, the mean age of patients ( 47 years) was relatively low; however this could be explained by the presence of patients between 17 and 24 years old. Histopathologic tests are the most important diagnostic tool to confirm the diagnosis of paraeoplastic dermatoses. They provide physicians enough credible information to look for a subjacent malingancy. In general, the histopathologic findings of the paraneoplastic dermatoses described in this study were similar to those reported worldwide. ${ }^{1-4}$

In our study, the most frequent neoplasm associated with paraneoplastic dermatoses was NonHodgkin's lymphoma. The dermatoses associated with this type of lymphoma were paraneoplastic immunobullous dermatoses, lymphomatoid papulosis, edema-
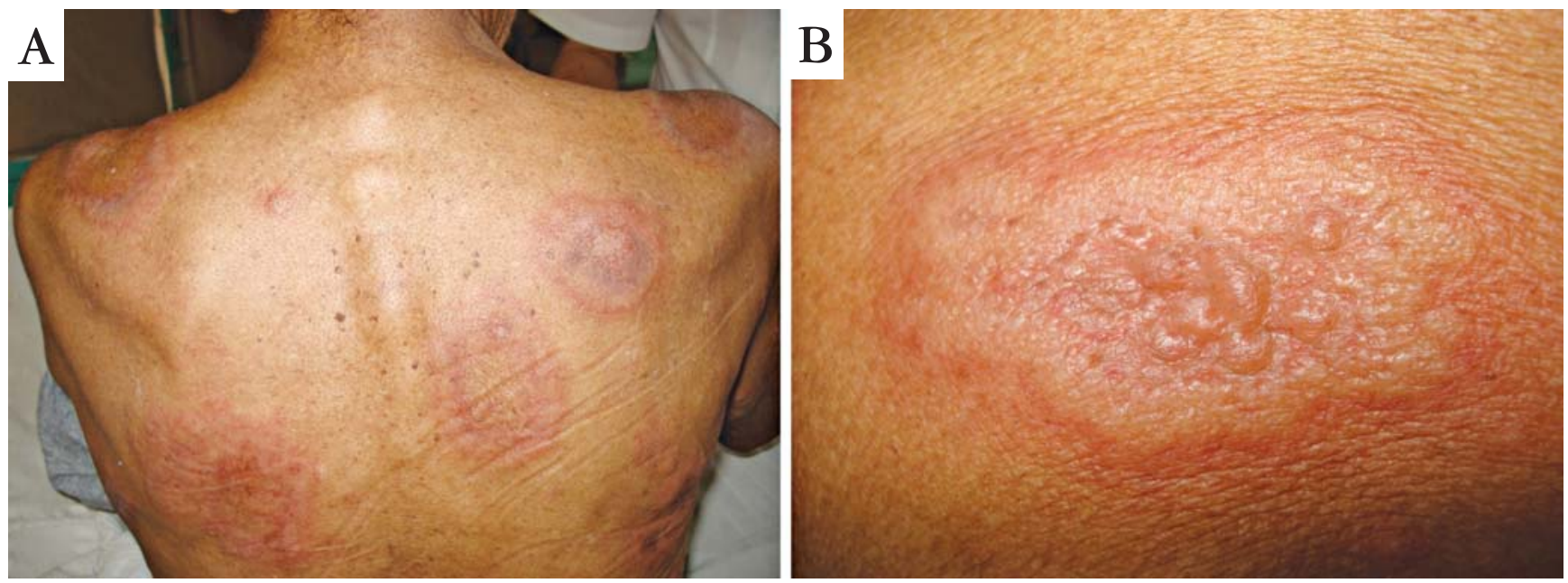

Figure 2: A. 73 year old male with vesicular infiltrated plaques; B. Vesicular infiltrated plaques (close up) 


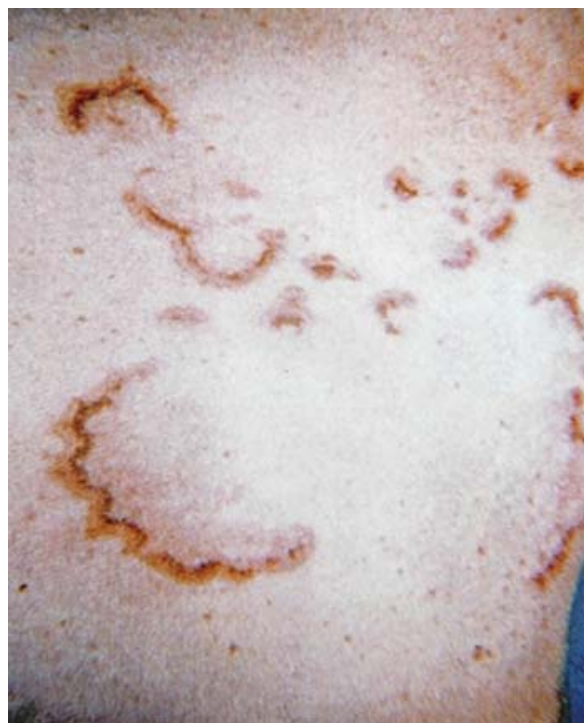

Figure 3: 65 year old female with circinate scaly papules tous scarring vasculitic panniculitis, norwegian scabies, infective dermatitis, generalized pruritus and acquired ichthyosis. It was previously described the association of lymphoproliferative neoplasm with acanthosis nigricans, Lesser-Trelat syndrome, paraneoplastic vasculitis and pityriasis liquenoides. ${ }^{5}$ Other authors have noted additional non-infectious dermatoses associations such as acquired ichthyosis, , ${ }^{1,4,6}$ immuno-bullous dermatosis, ${ }^{1,3,4}$ erythema annular centrifugum, ${ }^{1}$ pruritus, ${ }^{4}$ Sweet's syndrome, ${ }^{3,4}$ scleromyxedema, ${ }^{3}$ systemic amyloidosis, ${ }^{1}$ and infectious dermatitis such as norwegian scabies and infective dermatitis.

In our study, the most frequent solid tumor was adenocarcima of the upper digestive tract (esophagous and stomach), malignant neoplasm of pancreas and with less frequency neoplasms of the lung, breast, ovary and prostate. Dermatomyositis was the most frequent dermatosis. This disease has an unknown etiology, and it is characterized by the pres-

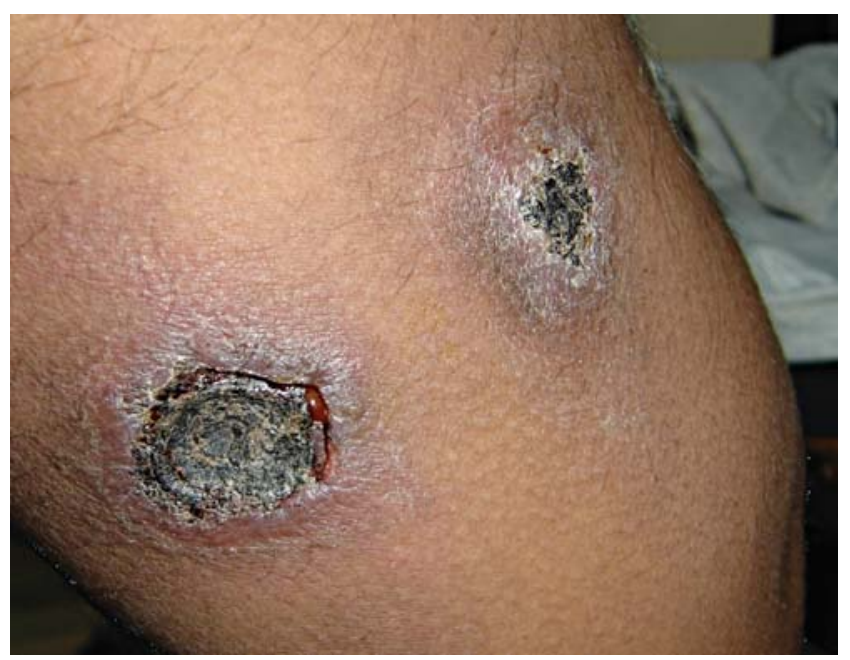

FIGURE 4: 19 year old female with crusted ulcers

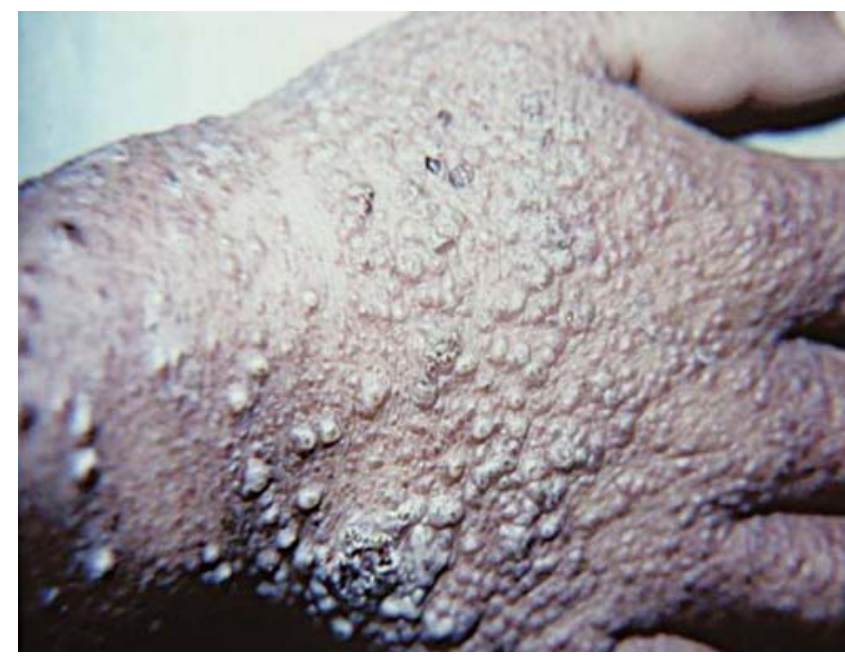

FiguRE 5: 17 year old female with crusted umbilicated papules

ence of inflammatory myopathy and typical cutaneous lesions. Dermatomyositis is associated with malignant neoplasia in between 6 and $60 \%$ of the cases, such as breast cancer (4-11\%), nasopharyngeal cancer (0-58\%) and ovarian cancer (2-12\%). ${ }^{8-10}$

Our results are similar to those reported previously, where the paraneoplastic dermatoses associated with solid tumors were muscoloskeletal disorders (including dermatomyositis), reactive erythemas, vascular dermatoses, papulosquamous disorders (acanthosis nigricans, tylosis, acquired ichthyosis) and growth of hair. ${ }^{10}$

Also, all our patients had a significant weight loss following the diagnosis of cancer. The course of the disease was fatal in most of them. ${ }^{11}$ Three (11.5\%) of our cases initiated with immuno-bullous disorders, but the rapid course and negative response to systemic corticosteroids were enough evidence to suspect the presence of malignancy, which were associa-

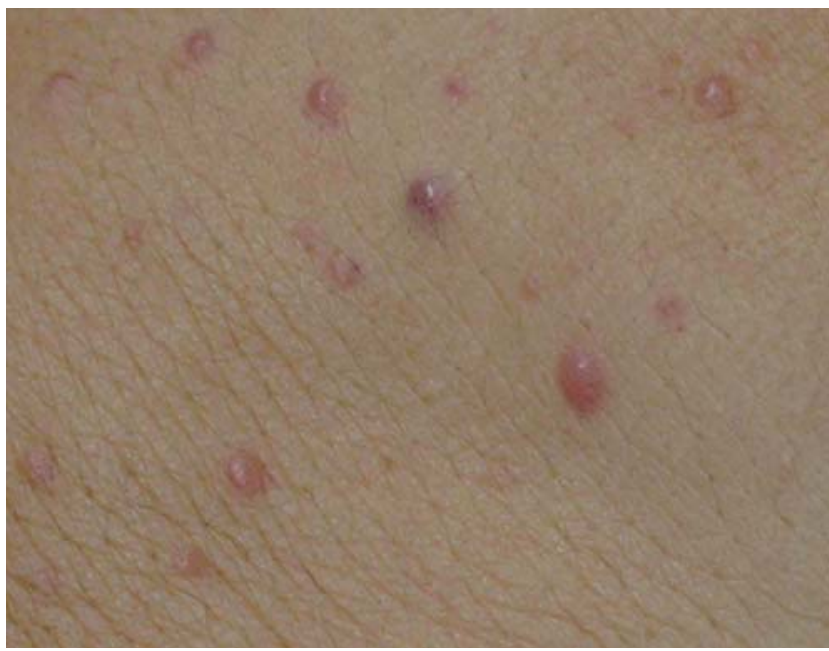

FIGURE 6: 60 year old female with yellowish hyperkeratotic papules 
TABle 3: Paraneoplastic dermatoses, underlying neoplasias and histopathologic findings

\begin{tabular}{|c|c|c|c|c|c|c|}
\hline $\begin{array}{l}\text { Patient } \\
\text { ID }\end{array}$ & $\begin{array}{l}\text { Dermatological } \\
\text { Diagnosis }\end{array}$ & Age & Gender & $\begin{array}{l}\text { Time of } \\
\text { Diagnosis }\end{array}$ & $\begin{array}{l}\text { Underlying } \\
\text { Neoplasia }\end{array}$ & Skin Biopsy \\
\hline PD1 & $\begin{array}{l}\text { Malignant acan- } \\
\text { thosis nigricans }(*)\end{array}$ & 33 & M & before & $\begin{array}{l}\text { Gastric } \\
\text { adenocarcinoma }\end{array}$ & $\begin{array}{l}\text { Orto/Hyeperkeratosis, papillomatosis and } \\
\text { increase of the pigment in the basal layer }\end{array}$ \\
\hline PD2 & $\begin{array}{l}\text { Palmoplantar kera- } \\
\text { toderma (tylosis) }\end{array}$ & 25 & M & $\begin{array}{l}\text { at the } \\
\text { same time }\end{array}$ & $\begin{array}{l}\text { Gastric } \\
\text { adenocarcinoma }\end{array}$ & $\begin{array}{l}\text { Compact and intense Orto/Hyperkeratosis, } \\
\text { moderate hypergranulomatosis, acanthosis } \\
\text { with papillomatosis in dermis. Mild inflamma- } \\
\text { tory infiltrate in papillary dermis }\end{array}$ \\
\hline PD3 & $\begin{array}{l}\text { Pemphigus } \\
\text { vegetants }\end{array}$ & 45 & M & $\begin{array}{l}\text { at the } \\
\text { same time }\end{array}$ & Thymoma & Suprabasal acantholytic cells \\
\hline PD4 & $\begin{array}{l}\text { Paraneoplastic } \\
\text { pemphigus }\end{array}$ & 38 & M & before & $\begin{array}{l}\text { T-cell cutaneous } \\
\text { lymphoma }\end{array}$ & $\begin{array}{l}\text { Suprabasal acantholytic cells and atypical lym- } \\
\text { phocytic cells CD } 4+\text { as false acantholytic cells }\end{array}$ \\
\hline PD5 & $\begin{array}{l}\text { Paraneoplastic } \\
\text { pemphigus }\end{array}$ & 55 & M & $\begin{array}{l}\text { at the } \\
\text { same time }\end{array}$ & $\begin{array}{l}\text { Non-Hodgkin } \\
\text { lymphoma }\end{array}$ & $\begin{array}{l}\text { Suprabasal acantholytic cells and necrosis of } \\
\text { the keratinocytes }\end{array}$ \\
\hline PD6 & Dermatomyositis & 60 & $\mathrm{~F}$ & before & Ovarian cancer & $\begin{array}{l}\text { Epidermal flattening, papillary dermal edema, } \\
\text { mucin }(+) \text { with Alcian Blue staining }\end{array}$ \\
\hline PD7 & Dermatomyositis & 42 & $\mathrm{~F}$ & before & Lung cancer & $\begin{array}{l}\text { Vacuolar degeneration of the basal layer and } \\
\text { papillary dermal edema }\end{array}$ \\
\hline PD8 & Dermatomyositis & 69 & M & before & $\begin{array}{l}\text { Esophagous } \\
\text { adenocarcinoma }\end{array}$ & $\begin{array}{l}\text { Vacuolar degeneration of the basal layer, pre- } \\
\text { sence of pigment in dermis, mucin deposits }\end{array}$ \\
\hline PD9 & Dermatomyositis & 50 & $\mathrm{~F}$ & $\begin{array}{l}\text { at the } \\
\text { same time }\end{array}$ & Breast cancer & $\begin{array}{l}\text { Vacuolar degeneration of the basal layer, pa- } \\
\text { pillary dermal edema }\end{array}$ \\
\hline PD10 & $\begin{array}{l}\text { Lymphomatoid } \\
\text { papulosis }(\$)\end{array}$ & 17 & $\mathrm{~F}$ & before & $\begin{array}{l}\text { Non-Hodgkin } \\
\text { lymphoma }\end{array}$ & Infiltrate in dermis of atypical lymphocytes \\
\hline PD11 & $\begin{array}{l}\text { Edematous scar- } \\
\text { ring vasculitic } \\
\text { panniculitis(\#) }\end{array}$ & 19 & M & $\begin{array}{l}\text { at the } \\
\text { same time }\end{array}$ & $\begin{array}{l}\text { Angiocentric cuta- } \\
\text { neous lymphoma }\end{array}$ & $\begin{array}{l}\text { Infiltrate of atypical lymphocytes in dermis, } \\
\text { vascular hyperplasia with leukocytoclasia }\end{array}$ \\
\hline PD12 & $\begin{array}{l}\text { Edematous scar- } \\
\text { ring vasculitic } \\
\text { panniculitis }\end{array}$ & 24 & M & $\begin{array}{l}\text { at the } \\
\text { same time }\end{array}$ & $\begin{array}{l}\text { Non-Hodgkin } \\
\text { lymphoma }\end{array}$ & $\begin{array}{l}\text { Infiltrate of atypical lymphocytes in dermis, } \\
\text { vascular hyperplasia with leukocytoclasia }\end{array}$ \\
\hline PD13 & Norwegian scabies & 34 & $\mathrm{~F}$ & before & $\begin{array}{l}\text { T-cell adult } \\
\text { lymphoma }\end{array}$ & $\begin{array}{l}\text { Accumulate of atypical lymphocytes (Pautrier's } \\
\text { abscess) in the stratum of Malphigi, dermis with } \\
\text { dense lymphohistiocytic inflammatory infiltrate }\end{array}$ \\
\hline PD14 & $\begin{array}{l}\text { Primary systemic } \\
\text { amyloidosis }(\&)\end{array}$ & 60 & $\mathrm{~F}$ & $\begin{array}{l}\text { at the } \\
\text { same time }\end{array}$ & Multiple myeloma & Presence of amyloid \\
\hline PD15 & $\begin{array}{l}\text { Necrolytic migra- } \\
\text { tory erythema(@) }\end{array}$ & 65 & $\mathrm{~F}$ & after & Glucagonoma & $\begin{array}{l}\text { Epidermal necrosis with intense inflammatory } \\
\text { mixed infiltrate }\end{array}$ \\
\hline PD16 & $\begin{array}{l}\text { Infective } \\
\text { Dermatitis }\end{array}$ & 35 & M & before & $\begin{array}{l}\text { T-cell cutaneous } \\
\text { lymphoma }\end{array}$ & $\begin{array}{l}\text { Hyper/Parakeratosis, acanthosis and vascular } \\
\text { hyperplasia of the superficial dermis }\end{array}$ \\
\hline PD17 & $\begin{array}{l}\text { Pancreatic } \\
\text { Panniculitis }\end{array}$ & 60 & $\mathrm{~F}$ & $\begin{array}{l}\text { at the } \\
\text { same time }\end{array}$ & $\begin{array}{l}\text { Adenocarcinoma } \\
\text { of the pancreas }\end{array}$ & Necrosis of adipocytes or "ghost cells" in dermis \\
\hline
\end{tabular}




\begin{tabular}{|c|c|c|c|c|c|c|}
\hline $\begin{array}{l}\text { Patient } \\
\text { ID }\end{array}$ & $\begin{array}{l}\text { Dermatological } \\
\text { Diagnosis }\end{array}$ & Age & Gender & $\begin{array}{l}\text { Time of } \\
\text { Diagnosis }\end{array}$ & $\begin{array}{l}\text { Underlying } \\
\text { Neoplasia }\end{array}$ & Histopathologic findings \\
\hline PD18 & $\begin{array}{l}\text { Pancreatic } \\
\text { Panniculitis }\end{array}$ & 58 & M & after & $\begin{array}{l}\text { Malignant neopla- } \\
\text { sia of the tail of } \\
\text { the pancreas }\end{array}$ & Necrosis of adipocytes or "ghost cells" in dermis \\
\hline PD19 & $\begin{array}{l}\text { Generalized } \\
\text { pruritus }\end{array}$ & 35 & M & before & $\begin{array}{l}\text { T-cell cutaneous } \\
\text { lymphoma }\end{array}$ & Superficial perivascular dermatitis \\
\hline PD20 & $\begin{array}{l}\text { Primary systemic } \\
\text { amyloidosis }\end{array}$ & 53 & M & before & Multiple myeloma & $\begin{array}{l}\text { Slimmed epidermis, dermis with liquenoid lym- } \\
\text { phocytic infiltrate. Presence of amyloid in dermis. }\end{array}$ \\
\hline PD21 & $\begin{array}{l}\text { Lesser-Trelat } \\
\text { syndrome }\end{array}$ & 76 & M & $\begin{array}{l}\text { at the } \\
\text { same time }\end{array}$ & $\begin{array}{l}\text { Adenocarcinoma } \\
\text { of prostate }\end{array}$ & $\begin{array}{l}\text { Laminated and digitiform hyperkeratosis and } \\
\text { ortokeratosis, acanthosis with papillomatosis }\end{array}$ \\
\hline PD22 & $\begin{array}{l}\text { Acquired } \\
\text { Ichthyosis }\end{array}$ & 53 & M & before & $\begin{array}{l}\text { T-cell adult } \\
\text { leukemia/ } \\
\text { lymphoma }\end{array}$ & $\begin{array}{l}\text { Orto/parakeratosis alternation. Acanthosis } \\
\text { with psoriasiform papillomatosis }\end{array}$ \\
\hline PD23 & $\begin{array}{l}\text { Sweet's syn- } \\
\text { drome }(+)\end{array}$ & 73 & M & $\begin{array}{l}\text { at the } \\
\text { same time }\end{array}$ & $\begin{array}{l}\text { Non-Hodgkin } \\
\text { Lymphoma }\end{array}$ & $\begin{array}{l}\text { Slimmed epidermis, edema in papillary der- } \\
\text { mis. Intense inflammatory reaction in medial } \\
\text { dermis with nutrophils premodimance. }\end{array}$ \\
\hline PD24 & Tripe palms & 50 & M & after & $\begin{array}{l}\text { T-cell } \\
\text { leukemia/lym- } \\
\text { phoma }\end{array}$ & $\begin{array}{l}\text { Intense orto/para hyperkeratosis. Discrete } \\
\text { lymphohistiocytic infiltrate in dermis. }\end{array}$ \\
\hline
\end{tabular}

(*)Fig 1a and 1b; (+) Fig 2a and 2b; (@) Fig 3; (\#) Fig 4; (\$) Fig 5; (\&) Fig 6

ted with lymphomas in two of them.

Four patients had ELISA positive serology for HTLV-I. These patients presented with infective dermatitis, norwegian scabies, acquired ichthyosis and tripe palms, which progressed to T-cell adult lymphoma. ${ }^{12}$

In general, only case reports and review articles have described the characteristics of paraneoplastic dermatoses. ${ }^{13,14,15}$ The paraneoplastic dermatoses seen in the patient population in a public hospital in Lima between 1993 and 2007 are rare entities with difficult clinical recognition and diagnoses. The early diagnosis might initiate the diagnosis of patients with an underlying malignancy. The surveillance is also hampered when patients do not have easy access to health care centers due to financial and geographical issues. For this reason, the early recognition of these cutaneous signs of internal malignancy is important not only for dermatologists but also for general practitioners, who have the opportunity to see patients first or are the only type of doctors in underserved areas.

In conclusion, the most common paraneoplastic dermatosis was dermatomyositis and the most frequent underlying malignancy was lymphoma. In our developing country, although most of the dermatoses were diagnosed before or concomitantly with the underlying neoplasia, the mortality rate remained high. 


\section{REFERENCES}

1. Cohen PR. Cutaneous paraneoplastic syndromes. Am Fam Physician. 1994; 50: 1273-82.

2. Boyce S, Harper J. Paraneoplastic dermatoses. Dermatol Clin. 2002; 20:523-32.

3. Chung VQ, Moschela SL, Zembowics A, Liu V. Clinical and pathologic findings of paraneoplastic dermatoses. J Am Acad Dermatol. 2006;54:745 - 62.

4. Ghul G, Arruabarrena C, Escalante L, Serrano P. Síndromes paraneoplásicos cutáneos. SEMERGEN. 2004;30:506-13.

5. Kempf W, Kutzner H, Kethelhack N, Palmedo G, Buró G. Paraneoplastic pityriasis lichenoides in cutaneous lymphoma: case report and review of the literature on paraneoplastic reactions of the skin in lymphoma and leukemia. Br J Dermatol. 2005;152:1327-31.

6. Patel N, Spencer LA, English JC, Zirwas MJ. Acquired Ichthyosis. J Am Acad Dermatol. 2006;55: 647-56.

7. Bergman JN, Dodd WA, Trotter MJ, Oger JJ, Dutz JP. Crusted scabies in association with human T-cell lymphotropic virus 1. J Cutan Med Surg. 1999;3:148-52.

8. Blas M, Bravo F, Castillo WJ, Ballona R, Navarro P, Catacora J, Cairampoma R, Gotuzzo E. Norwegian scabies in Peru: The impact of Human T-Cell Lymphotropic Virus type I infection. Am J Trop Med Hyg. 2005;72:855-7.

9. Callen JP, Wortmann RL. Dermatomyositis. Clin Dermatol. 2006;24:363-73.

10. Mebazaa A, Boussen H, Nohuira R, Rokbani L, Ben OsmanDhahri A, Bouaouina N, et al. Dermatomyositis and malignancy in Tunisia: a multicenter national retrospective study of 20 cases. J Am Acad Dermatol. 2003;48:530-4.

11. Wade MS, Black MM. Paraneoplastic pemphigus: a brief update. Australas J Dermatol. 2005;46:1-10.

12. Shuh $\mathbf{M}$, Beilke $M$. The human T-cell leukemia virus type 1 (HTLV-1): new insights into the clinical aspects and molecular pathogenesis of adult T-cell leukemia/lymphoma (ATLL) and tropical spastic paraparesis/HTLV-associated myelopathy (TSP/HAM). Microsc Res Tech 2005; 68:176-96.

13. Piscoya A, Ríos $R$, Valdivia $J$, Cedrón $H$, HuertaMercado J, Bussaulleu R. Acantosis nigricans maligna: Reporte de un caso y revisión de la literatura. Rev Gastroenterol Peru 2005;25:101-5.

14. Kumakawa Z, Chávez-De-Paz P, Galarza C, Morales D, Mayhua A, Peching G, Benavides A, Rafael A, Valladares G. Pancreatic Panniculitis. Dermatol Peru 2004;14:208 -11.

15. Gadwin-Sánchez F. Signos cutáneos de malignidad interna. Dermatol Peru 2005; 15: 181-5.

MAILING ADDRESS / ENDEREÇO PARA CORRESPONDÊNCIA: Alex G Ortega-Loayza

Department of Internal Medicine

Virginia Commonwealth University PO

Box 980509, Richmond, VA 232980509

Tel./Fax: 9196194096 / 8048284926

E-mail: aortegaloayza2@mcvb-vcu.edu

How to cite this article/Como citar este artigo: Ortega-Loayza AG, Ramos W, Gutierrez EL, Chavez de Paz P, Bobbio L, Galarza C. Cutaneous Manifestations of internal malignancies in a tertiary health care hospital of a developing country. An Bras Dermatol. 2010;85(5):736-42. 